\title{
Molecular Epidemiology of Epstein-Barr Virus in Women Breast Cancer in Congo Brazzaville
}

\author{
Dimitry Moudiongui Mboungou Malanda ${ }^{1,2,5}$, Anicet Luc Magloire Boumba ${ }^{1,3}$, \\ Fabien Gaël Mouamba ${ }^{1,2}$, Landry Martial Miguel ${ }^{1,2,5}$, Donatien Moukassa ${ }^{1,4}$, \\ Jean Félix Peko ${ }^{1,2}$, Ange Antoine Abena ${ }^{1,2,3}$ \\ ${ }^{1}$ Faculty of Health Sciences, Marien Ngouabi University of Brazzaville. ${ }^{5}$ Oncology Department, Hospital. \\ ${ }^{2}$ Anatomy and Pathological Cytology Department, Brazzaville Hospital and University Center (CHUB). \\ ${ }^{3}$ Laboratory of Medical and Morphological Analysis, General Hospital of Loandjili in Pointe-Noire (HGL). \\ ${ }^{4}$ Pathological Anatomy and Cytology Department, Edith Lucie Bongo Ondimba General Hospital in Oyo \\ (HGELBO). \\ ${ }^{5}$ Dénis University Sassou Nguesso
}

Corresponding Author: Dimitry Moudiongui Mboungou Malanda

\begin{abstract}
Introduction: the Epstein Barr virus is one of the very first oncogenic viruses to be identified as responsible for human malignancies. Its role as an etiological agent of breast cancer remains controversial, however, despite the growing molecular evidence. The aim of this study was detected the presence of EBV DNA in patients with breast cancer in the Republic of Congo.

Methods: The study was conducted on 90 samples of formalin fixed and paraffin-embedded tissue blocks (FFPE) from breast cancer tissue. The immunohistochemistry technique was used to test for the expression of the LMP1 antibody and DNA was extracted from all blocks of formalin-fixed and paraffin-embedded breast cancer tissue (FFPE) to detect presence of EBV 1 DNA by real-time polymerase chain reaction (PCR).

Results: EBV was detected in 12.33\% (12/90) of formalin-fixed, paraffin-embedded (FFPE) breast cancer tissue blocks. All formalin-fixed, paraffin-embedded (FFPE) breast cancer tissue blocks with positive EBV DNA were high tumor grades (II and III). Overall EBV infection with clinicopathological features of breast cancer cases showed no significant difference $(\mathrm{P}>0.05)$. However, a statistically significant difference was observed between EBV infection and histological types $(\mathrm{P}=0.04)$.

Conclusion: Our results provide evidence for the presence of EBV DNA in female breast cancer in Congo Brazzaville. However, this evidence is substantial but inconclusive for the involvement of viruses in the development of breast cancer. Therefore, future investigations will be needed to elucidate the exact role of EBV in breast cancer in women in the Republic of Congo.
\end{abstract}

Key Words: EBV, breast cancer, women, Congo Brazzaville.

\section{INTRODUCTION}

The majority of humans have come into contact with the Epstein-Barr virus (EBV) which is a human gamma herpes virus [1, 2, 3]. The Epstein Barr virus is one of the very first oncogenic viruses to be identified as responsible for human malignancies. It infects lymphoid cells and epithelial cells in the oropharynx. Its association with Burkitt's lymphoma and other cancers, particularly gastric, is strongly documented $[4,5,6,7,8]$. In addition, it has recently been pointed out that oncoviruses, such as high-risk human papillomavirus (HPV) and Epstein-Barr virus (EBV), may be involved in the onset and progression of breast cancer $[9,10,11$, 12]. 
Likewise, a variable frequency of EBV infection has been reported; in Jordan, Pakistan, Portugal and Eritrea, EBV was present in 24-28\% [13], while a higher frequency was reported in Qatar (49\%), Syria (52\%) and in Sudan (53\%), respectively $[9,14,15]$. Its role as an etiological agent of breast cancer remains controversial, however, despite the increasing molecular evidence [16, 17, 18]. Although the etiology of breast cancer is not fully understood, exposure to Epstein-Barr virus (EBV) is suggested as a risk factor for breast cancer [19]. The involvement of EBV in this group of breast cancers could have important etiopathogenic, preventive and therapeutic consequences. To understand why this issue remains controversial and how it might be resolved, in this article, we first examine the evidence for the presence of the EBV genome in selected cases of female breast cancer in Congo Brazzaville.

In Congo, the incidence of breast cancer has been galloping for a few years to the point, it has become the first incidence of all cancers diagnosed in 2020 according to the latest data from Globocan2020 [20, 21]. Therefore, it is important to seek to know the causes of the increase in the incidence of breast cancer in Congo by looking for other risk factors or association link of an infectious agent with the malignant pathology of the breast. breast.

The possible contribution of EBV to the development and progression of breast cancer is still controversial. In Congo, there are no published data on EBV and breast cancer. To help fill this knowledge gap, we conducted a preliminary study to detect the EBV genome by real-time PCR in 10\% formalin fixed and paraffin-embedded breast cancer tissue samples in women in the Republic of Congo.

\section{MATERIAL AND METHODS}

It is a descriptive and cross-sectional study. Data collection was retrospective and prospective by analyzing the outcome registers for breast cancer cases. These cases were listed in the pathological cytology anatomy laboratory of the Brazzaville university hospital center, during the period 2014-2020. They were selected on the basis of the availability of tumor tissue fixed in formalin and coated in paraffin with a pathological diagnosis confirmed after re-reading of the slides by two pathologists. The paraffin blocks of cancerous breast tissue were for Congolese women. Their serological profile for EBV was not known.

The immunohistochemical study was carried out on tissue fixed in formalin and coated in paraffin, with the anti-LMP1 antibody (clone EBS-I-025, Thermo Fisher) of EBV and data on the various phenotypic characteristics such as expression of hormone receptors (estrogen receptors (ER) or progesterone (PR)). Antigenic unmasking was carried out by treatment with Bain Marie set at $95^{\circ} \mathrm{C}$.

Detection of the presence of EBV DNA in breast cancer cases was performed using a Magnetic Induction Thermal Cycler (Mic). The latter, located in the molecular biology laboratory of the Marie Madeleine GOMBES Foundation in Pointe-Noire, allows real-time PCR to be carried out. The systems consist of a personal computer and pre-loaded software to run the tests and view the results. Positive and negative controls were included in each run.

Genomic DNA was extracted from malignant breast tissue fixed in $10 \%$ formalin and embedded in paraffin. Next, we performed real-time polymerase chain reaction (PCR) to detect EBV DNA. To extract the DNA, malignant breast tissues fixed in $10 \%$ formalin and embedded in paraffin were cut into $10 \mu \mathrm{m}$ thick using a microtome. Dewaxing was carried out by adding $1 \mathrm{ml}$ of xylene. Then we centrifuged the samples for $5 \mathrm{~min}$ and the supernatants were removed. This step was repeated once, then $1 \mathrm{ml}$ of $96 \%$ ethanol was added. The microtubes were placed in a heat block at 50 - C until the ethanol was completely dry. Then, digestion was carried out by adding digestion buffer and proteinase $\mathrm{K}$ solution. 
The "RNA / DNA purification kit" (PROMEGA) was used for DNA extraction. Once the tissue was digested, we added 800 $\mu \mathrm{l}$ of $90^{\circ} \mathrm{C}$ ethanol (Cooper) to each tube containing the samples. The mixture was homogenized and extracted according to the manufacturer's instructions. The DNA extracts obtained were measured with a Qubit 3.0 fluorometer to assess the concentration of DNA. The extracted DNA was stored at $-70^{\circ} \mathrm{C}$ until amplification by real-time PCR.

The Epstein-Barr Virus Quantitative PCR Kit (Ref: Dia-EBVQ-200.Vs1) in Real Time is a quantitative in vitro diagnostic test for the rapid and specific detection of human Epstein-Barr virus (VEB) in samples by the real-time polymerase chainization technique. The primers used were the forward primer EBV p143 (5'GGA.ACC.TGG.TCA.TCC.TTG.C-3') and the reverse primers EBV p143 (5'ACG.TGC.ATG.GAC.CGG.TTA.AT-3'),

which were synthesized at Isogen Biosciences (Maarssen, The Netherlands).

A fluorogenic probe (5'CGC.AGG.CAC.TCG.TAC.TGC.TCG.CT3') was synthesized by PE Biosystems with a FAM reporter molecule attached to the 5 'end and a TAMRA quencher linked to the end. 3 '[22]. Real-time PCR amplification was performed in a volume of $25 \mu \mathrm{l}$ containing $12.5 \mu \mathrm{l}$ (qPCR Mix), $2.5 \mu \mathrm{l}$ Primers / Probes, $5 \mu \mathrm{l}$ of molecular biology water and $5 \mu$ of each sample or control. Amplification and detection were performed by a real-time PCR machine (magnetic induction cycler: Mic). The thermal cycles used for the detection of EBV DNA were amplified for initial denaturation at $95^{\circ} \mathrm{C}$ for $10 \mathrm{~min}$, followed by 45 cycles of $95^{\circ} \mathrm{C}$ for $10 \mathrm{~s}$ and hybridization at $40^{\circ} \mathrm{C}$ for $30 \mathrm{~s}$ and a final elongation for $30 \mathrm{~s}$ at $72^{\circ} \mathrm{C}$.

\section{Statistical analyzes}

The following software was used: Microsoft Excel version 2016 for the creation of the database and Graph Pad Prism version 5.0.0.3 for the data processing. Results were expressed as mean \pm standard deviations for quantitative variables and as number and / or percentage for qualitative variables. The comparison of the qualitative variables was made by the Chi square test and that of the quantitative variables by the Student's $\mathrm{t}$ test. The $\mathrm{p}$ values $\quad(\mathrm{P} \leq 0.05) \quad$ were considered statistically significant.

\section{RESULTS}

Our study involved 90 patients ranging in age from 22 to 80 years. The average age was 46.78 years. The age range of EBV positive patients was between 25 and 71 years (mean age 41.83 years). The 90 cases studied corresponded to 64 nonspecific invasive carcinomas (CITNS), 20 invasive lobular carcinomas (CLI), 4 mixed carcinomas $(\mathrm{CMx})$ and 2 medullary carcinomas (CM). The most dominant histologic diagnosis of all positive cases was CITNS (58.33\%). The SBR grade was specified in all 90 cases, for EBV positive breast cancer cases, $66.67 \%$ (8/12) had SBR grade III. Hormone receptors, studied by immunohistochemistry in all cases (90), were positive 63 (70\%) and negative in 27 cases (30\%). The immunohistochemical study showed cytoplasmic positivity in tumor cells for the LMP1 protein in 12 cases (13.33\%) among the 90 studied (FIG. 1A). However, non-tumor epithelial cells as well as stromal lymphoid cells were in all cases negative. Real-time PCR analysis of EBV DNA confirmed the results of immunohistochemistry. Indeed, the amount of fluorescence emitted from the presence of EBV DNA was detected in tumor cells only in 12 cases (13.33\%) (Figure 1B). Table 1 summarizes the anatomoclinical characteristics of the $12 \mathrm{EBV}$ positive breast malignancies. non-tumor epithelial cells as well as stromal lymphoid cells were all negative. Real-time PCR analysis of EBV DNA confirmed the results of immunohistochemistry. Indeed, the amount of fluorescence emitted from the presence of EBV DNA was detected in tumor cells only in 12 cases (13.33\%) (Figure 1B). Table 1 summarizes the anatomoclinical 
Dimitry Moudiongui Mboungou Malanda et.al. Molecular epidemiology of epstein-barr virus in women breast cancer in Congo Brazzaville.

characteristics of the $12 \mathrm{EBV}$ positive breast malignancies. non-tumor epithelial cells as well as stromal lymphoid cells were all negative. Real-time PCR analysis of EBV DNA confirmed the results of immunohistochemistry. Indeed, the amount of fluorescence emitted from the presence of EBV DNA was detected in tumor cells only in 12 cases (13.33\%) (Figure 1B). Table 1 Anatomoclinical characteristics of positive
EBV tumors. Overall EBV infection with clinicopathological features of breast cancer cases showed no significant difference $(\mathrm{P}>0.05)$. However, a statistically significant difference was observed between EBV infection and histological types $(\mathrm{P}=0.04)$ Table 2. Distribution of HPV infection according to clinicopathological features.

Table 1. Anatomoclinical characteristics of positive EBV tumors.

\begin{tabular}{|l|l|l|l|l|l|l|}
\hline $\mathbf{n}^{\circ}$ & Age (years) & SBR & Histological type & Hormone receptors & LMP1 & PCR \\
\hline 1 & 33 & I & CM & Positive & Positive & Positive \\
\hline 2 & 25 & II & CM & Positive & Positive & Positive \\
\hline 3 & 71 & III & CITNS & Negative & Positive & Positive \\
\hline 4 & 25 & III & CITNS & Negative & Positive & Positive \\
\hline 5 & 61 & III & CITNS & Positive & Positive & Positive \\
\hline 6 & 55 & II & CITNS & Positive & Positive & Positive \\
\hline 7 & 33 & III & CITNS & Positive & Positive & Positive \\
\hline 8 & 38 & III & CITNS & Positive & Positive & Positive \\
\hline 9 & 34 & III & CITNS & Positive & Positive & Positive \\
\hline 10 & 46 & III & CLI & Positive & Positive & Positive \\
\hline 11 & 31 & III & CLI & Negative & Positive & Positive \\
\hline 12 & 50 & II & CLI & Negative & Positive & Positive \\
\hline
\end{tabular}

Table 2. Distribution of HPV infection according to clinicopathological features

\begin{tabular}{|c|c|c|c|c|}
\hline Clinicopathological features & Total $(n=40)$ & \multicolumn{2}{|c|}{ EBV infection EBV +, n(\%) EBV -, n(\%) } & $p$-value $(p>0.05)$ \\
\hline \multicolumn{4}{|l|}{ Ages (years) } & \multirow{5}{*}{$p^{-v a i c u e ~}(p-0.00)$} \\
\hline$\leq 40$ & 30 & $7(23,33)$ & $23(76,67)$ & \\
\hline $41-56$ & 37 & $3(25)$ & $12(75)$ & \\
\hline $57-71$ & 21 & $2(20)$ & $8(80)$ & \\
\hline$\geq 72$ & 2 & $0(0)$ & $5(100)$ & \\
\hline \multicolumn{4}{|l|}{ Lateralities } & \multirow{5}{*}{0,11} \\
\hline Left & 31 & $4(13)$ & $27(87)$ & \\
\hline Right & 43 & $4(9)$ & $39(81)$ & \\
\hline Bilateral & 3 & $1(33,3)$ & $2(6,67)$ & \\
\hline Unknown & 13 & $3(23,1)$ & $10(76,9)$ & \\
\hline \multicolumn{4}{|l|}{ Histological Types } & \multirow{5}{*}{$0,04 *$} \\
\hline Non-specific type carcinoma & 64 & $7(11)$ & $57(89)$ & \\
\hline Lobular carcinoma & 20 & $3(15)$ & $17(85)$ & \\
\hline Carcinoma mixte & 4 & $0(0)$ & $4(100)$ & \\
\hline Carcinoma Medullary & 2 & $2(100)$ & $0(0)$ & \\
\hline \multicolumn{4}{|l|}{ Grade SBR } & \multirow{4}{*}{0,88} \\
\hline Grade I & 13 & $1(13)$ & $12(87)$ & \\
\hline Grade II & 49 & $3(6)$ & $15(94)$ & \\
\hline Grade III & 28 & $8(28,6)$ & $18(71,4)$ & \\
\hline \multicolumn{4}{|l|}{ Molecular subtypes } & \multirow{7}{*}{0,46} \\
\hline $\mathrm{RH}(\mathrm{RO}+\mathrm{RP})+$ & 63 & $8(12,7)$ & $55(87,3)$ & \\
\hline RH (RO+RP)- & 27 & $4(14,8)$ & $23(85,2)$ & \\
\hline HER2+ & 23 & $10(43,5)$ & $13(56,5)$ & \\
\hline HER2- & 67 & $2(3)$ & $2(97)$ & \\
\hline $\mathrm{Ki} 67 \leq 14$ & 49 & $1(2)$ & $48(98)$ & \\
\hline $\mathrm{Ki} 67 \geq 15$ & 41 & $11(27)$ & $30(73)$ & \\
\hline
\end{tabular}

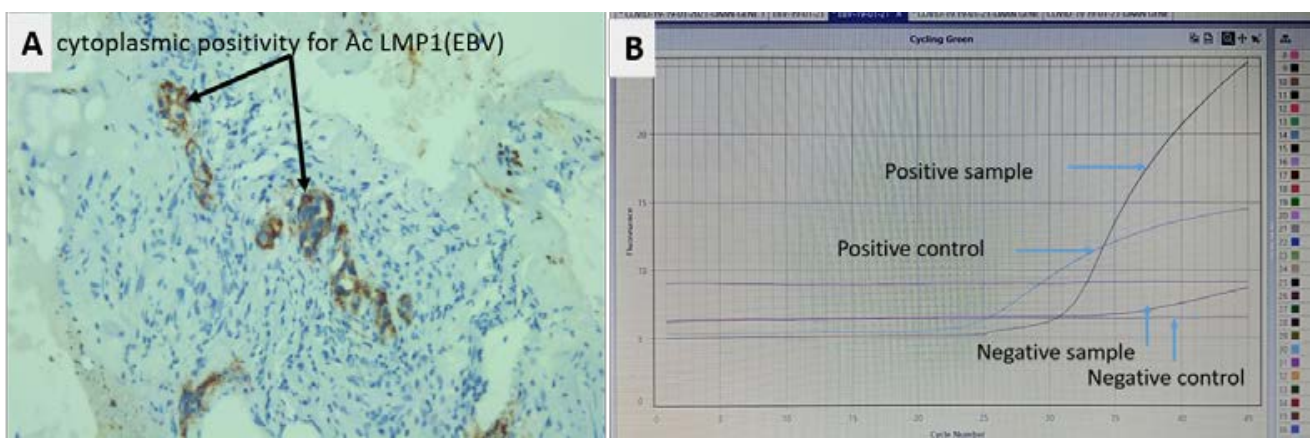

Figure 1. A : Cytoplasmic positivity of tumor cells for LMP1 (immunohistochemistry x 200). B : Real-time PCR results with Mic systems. 


\section{DISCUSSION}

The worldwide increase in the incidence and mortality of breast cancer is considerable [23, 24]. The rate of breast cancer is increasing by about $3 \%$ per year [25]. Breast cancer is a multifactorial disease; the role of the infectious agent in this disease is remarkable. The high incidence of breast cancer in the world has drawn the scientist's attention to the viral etiology of breast cancer. Viral agents play a crucial role as carcinogens and they are associated with almost $20 \%$ of cancers. The development of molecular techniques and subsequent investigations have proven the carcinogenic effect of EBV in various tumors [4, 5, 26]. Although many studies have been performed, no etiological factors for human breast cancer have been known. Recent research has shown the association of breast cancer and viral infections, such as Epstein-Barr virus (EBV), human papillomavirus (HPV), and mouse mammary tumor virus (MMTV) [27].

Formalin fixed and paraffin embedded tissues (FFPE) support tissue structure for the histopathological diagnosis of diseases such as cancer are commonly used worldwide [28, 29]. The detection and characterization of new viruses is often an obstacle to the lack of adequately stored material. Formalin-fixed paraffin-coated tissues (FFPE) can be used to detect known viral sequences [30, 31]. The viral RNA was extracted from a sample of FFPE lung tissue from a victim of the 1918 pandemic, the "Spanish" influenza A / H1N1 virus, this virus was characterized and then recovered by reverse genetics [32].

EBV is a widespread human pathogen which causes infectious mononucleosis in approximately $10 \%$ of individuals during the primary infection. EBV infection most commonly occurs early in life, with around $30 \%$ of children being HIV positive by 5 years, $50 \%$ by 10 years and up to $80 \%$ by 18 years [33]. This infecting human herpesvirus has also been associated with post-transplant lymphoproliferative disease [34] and may play a role in certain autoimmune diseases [35, 36, 37,38]. In addition, EBV has oncogenic properties and is involved in the pathogenesis of several types of cancer, mainly Burkitt's lymphoma, Hodgkin's and non-Hodgkin's lymphoma, carcinoma of the nasopharynx and gastric carcinoma [39, 40]. More than $5 \%$ of the 2 million new cancer cases associated with infection in 2008 could be attributed to EBV [41] ; it would also have caused $1.8 \%$ of cancer deaths in 2010 , or more than 140,000 cases [42].

The particular biological properties of EBV are at the origin of the remarkable variety of pathologies associated with this virus and its worldwide distribution. In certain pathologies, EBV is present in almost all cases and in almost all cells; this is the case with Burkitt's lymphoma, undifferentiated carcinoma of the nasopharynx, primary cerebral lymphomas in patients with AIDS, lymphoproliferations in transplant patients and $\mathrm{T} / \mathrm{NK}$ lymphomas of the nasopharynx. In other pathologies such as Hodgkin's disease, EBV is inconstantly found [43, 44]. In addition, EBV has been proposed since 1995 to contribute to the development of breast cancer. [45]. Its role as an etiological agent of breast cancer remains controversial, however, despite increasing molecular evidence [46, 47].

The association of EBV with certain primary mammary lymphomas and the similarity of medullary carcinoma with undifferentiated nasopharyngeal-type carcinoma closely linked to EBV has prompted some authors to search for this virus in breast cancer, particularly with lymphoid stroma. which includes medullary carcinoma and high-grade invasive ductal carcinoma with lymphoid stroma [48]. Published studies have used different methods and report controversial results. We found only two studies in the literature that looked at bone marrow carcinomas. In these two series, all the cases studied were negative for EBV [49, 50]. On the other hand, our study shows the presence of EBV 
DNA in 2 medullary carcinomas out of the 2 studied.

Fina et al. conducted a retrospective study of 509 cases of breast cancer in women from different geographic areas according to the incidence of EBV infection; this virus was detected in $31.8 \%$ of mammary carcinomas, while it was absent in non-tumor mammary epithelial cells and in stromal lymphoid cells. Regarding the geographical distribution, these authors did not find a difference in the association of EBV with breast cancer, unlike carcinoma of the nasopharynx and Burkitt's lymphoma [51]. Bonnet et al., In a study of 100 breast carcinomas, detected EBV by PCR in $51 \%$ of cases. In addition, the presence of EBV had a poor prognostic significance: high histological grade, with negative hormone receptors and a higher rate of lymph node metastases.[48]. These results are far superior to those found in our study; in terms of percentage detection of EBV DNA by real-time PCR. Indeed, in our study $13.33 \%(12 / 90)$ were positive for the detection of EBV DNA by real-time PCR, but a point of convergence in relation to the aggressiveness of breast cancer having tested positive for EBV.

In this study, the prevalence of breast cancer samples in which Epstein Barr virus (EBV) was detected was 12 samples fixed in $10 \%$ formalin and embedded in breast cancer paraffin either $13.33 \%$. This prevalence of EBV DNA detection status in our study is low compared to that found in the world or in Asia. Indeed, the epidemiological studies conducted by Huo, Zhang and Yang on the basis of the PCR examination, the prevalence of EBV infection in the world is $29.32 \%$ and the prevalence in Asia is $35.25 \%$ [52]. The higher incidence may be caused by demographic differences and the characteristics of the research sample. Results from other studies have also demonstrated an overall prevalence ranging from $26.37 \%$ to $28 \%$ for EBV infection in patients with malignant breast tumors worldwide [53]. While a high frequency of
55.5\% of detection of EBV DNA in women with breast cancer has been reported in Sudan [54]. On the other hand, the results of our study are superior to those reported respectively by Naushad et al., and by Mofrad et al. who described the low frequency of $7.3 \%$ in Pakistan and $6.7 \%$ in Iran of EBV DNA among breast cancers $[55,56]$.

Breast cancer linked to the virus has been shown to have a poor prognosis, especially when multiple viruses are detected in breast samples. EBV positive breast cancer has been shown to have more aggressive characteristics [57]. In our present study, the high incidence of $58.33 \%$ of EBV DNA was found among grade III breast cancer specimens, indicating the possible role that EBV may play in the aggressiveness of breast cancer. malignant breast tumors.

Furthermore, the role of latent EBV antigens EBNA1, EBNA2, EBNA3C and LMP1 is often essential for the transformation and immortalization of cells infected with EBV, which leads to cancers [58].

LMP-1 is directly related to oncogenesis, as it is able to activate several cell signaling pathways such as nuclear factor-кB, c-Jun NH2-terminal kinase (JNK), p38 kinase, phosphatidylinositol 3 kinase (PI3K), and several other possible pathways, resulting in continued proliferation and inhibiting apoptosis [59]. The expression of LMP1 by cells infected with EBV depends on the type of viral latency and its negativity does not eliminate the presence of EBV [60]. In our series, detection of EBV latency type II (positive LMP1) by immunohistochemistry was found in 12 cases out of the 90 studied, i.e. $13.33 \%$. This positivity was limited to carcinoma epithelial cells and rarely to stromal lymphoid cells; these 12 LMP1 positive cases were also positive on realtime PCR (i.e. a 100\% correlation of cases).

One of the oncoproteins found in Epstein-Barr virus is EBNA-1. The oncogenic role of the EBNA-1 protein has 
been pointed out by some previous researchers. EBNA-1 can reduce p53 levels by triggering ubiquitin specific protease USP7 so that p53 becomes unstable. Ultimately, the mammary gland epithelium becomes infected with EBV, so the cells continually proliferate and become antiapoptotic [61]. In our study, we could not test for expression by immunohistochemistry of the oncoprotein EBNA-1 in our samples fixed with $10 \%$ formalin and embedded in breast cancer paraffin.

Other studies failed to detect EBV in breast cancer [62, 63]. Thus, the analysis of the various studies reported shows controversial results concerning the association of EBV and breast cancer, this variability would be due to several factors, in particular the sensitivity which varies between the different techniques used as well as the reduced number of reported cases [50, 64]. Geographically, the molecular prevalence of these viruses in breast cancer varies. Another point is that biopsy samples show more positive results than FFPE samples, indicating that biopsy samples (fresh or frozen) are more suitable and more sensitive than other samples for the detection of EBV. Furthermore, the limited amount of genomic DNA extracted and DNA fragmentation are problems associated with the use of FFPE samples [65]. It can be concluded that the heterogeneity of the results of the different studies could be attributed to several variables, notably the geographical location, the methods used to detect EBV infection, the type of samples, regions or detection genes in the EBV genome; and histological types of breast cancer. Other cofactors and / or particular predispositions in the population (genetic, geographic, ethnic, etc.) could be related to the relatively high association rate found in certain cases.

Detection of EBV in tumor cells does not make it possible to attribute a certain oncogenic role to this virus. According to Labreque et al, the presence of EBV can be explained by the passage of
EBV in neoplastic epithelial cells after its reactivation in circulating $\mathrm{B}$ lymphocytes and EBV in this case does not play a direct role in the oncogenesis [66].

Overall EBV infection with clinicopathological features of breast cancer cases showed no significant difference $(\mathrm{P}>0.05)$. However, a statistically significant difference was observed between EBV infection and histological types $(\mathrm{P}=0.04)$.

In the current state of knowledge, an implication of EBV in breast cancer remains a plausible hypothesis. The Epstein Barr virus is one of the very first oncogenic viruses to be identified as responsible for human malignancies. Its role as an etiological agent of breast cancer remains controversial, however, despite the growing molecular evidence. Several points relating to the role of EBV in this cancer will be clarified in the future. Although the etiology of breast cancer is not fully understood, exposure to Epstein-Barr virus (EBV) is suggested as a risk factor for breast cancer.

Limitations of our study included the unavailability of in situ hybridization (ISH) to detect viral gene expression to determine whether EBV is associated with malignant cells, the lack of serological test results for EBV and the expression of the oncoprotein EBNA-1 and a control group of healthy breast tissue.

\section{CONCLUSION}

Based on our results and the review of other studies in the literature, it can be concluded that EBV may have an etiological role in breast cancer. No significant association between the pathological subtype and the presence of EBV-DNA was identified in our study. The study on EBV and breast cancer in Congolese women was carried out to detect the presence of EBV virus DNA in malignant breast tumors. Although the presence of a virus alone does not establish a causal role in the disease, our results are positive at $13.33 \%$ of the detection of EBV DNA in our female breast cancer samples in the Republic of Congo. 


\section{Acknowledgement:}

We thank the Marien Ngouabi University (UMNG) and the doctoral training in Health and Human Biology (SBH) of the Faculty of Health Sciences (FSSA) for their training offer. We would like to thank the Brazzaville University Hospital Center (CHUB) as well as the Marie Madeleine GOMBES Foundation for their support in the collection of samples but also for their technical support.

\section{Funding} funding.

This work did not receive specific

\section{Conflicts of Interest}

The authors declare no conflict of interest.

\section{Contributions from the authors}

Dimitry Moudiongui: conception and writing of the article; Anicet Boumba: data analysis and interpretation Fabien Gaël MOUAMABA: critical review of the article; Landry Martial MIGUEL: critical review of the article; Fidèle Mambouene: critical review of the article; Donatien Moukassa: critical review of the article; Jean Félix Peko: critical review of the article; Ange Antoine ABENA: final approval of the version to be published. All authors have read and approved the final version of the manuscript.

\section{Ethical Approval: Approved}

\section{REFERENCES}

1. Shannon-Lowe, C.; Rowe, M. Epstein Barr virus entry; kissing and conjugation. Curr. Opin. Virol. 2014, 4, 78-84.

2. Farrell, PJ Epstein - Barr Virus and Cancer. Annu. Rev. Pathol. Mech. Say. 2019, 14, 29-53.

3. Pattle, SB; Farrell, PJ The role of Epstein Barr virus in cancer. Expert Opin. Biol. Ther. 2006, 6, 1193-1205.

4. Xue, F.; He, X. Epstein - Barr Virus DNA in Nasopharyngeal Carcinoma: A Brief Review. Methods Mol. Biol. 2020, 2204, 99-107.
5. Chen, Y.-P.; Chan, ATC; Le, Q.-T.; Blanchard, P.; Sun, Y.; Ma, J. Nasopharyngeal carcinoma. Lancet 2019, 394, 64-80.

6. Yu F, Lu Y, Li Y, Uchio Y, Pangnguriseng UA, Kartika AV, et al. Epstein - Barr Virus Infection of Pseudostratified Nasopharyngeal Epithelium Disrupts Epithelial Integrity. Cancers. 2020 Sep; 12 (9): 2722.

7. Naseem, M.; Barzi, A.; Brezden-Masley, C.; Puccini, A.; Berger, MD; Tokunaga, R.; Battaglin, F.; Soni, S.; McSkane, M.; Zhang, W.; et al. Outlooks on Epstein-Barr virus associated gastric cancer. Cancer Treat. Rev. 2018, 66, 15-22.

8. Fukayama, M.; Abe, H.; Kunita, A.; Shinozaki-Ushiku, A.; Matsusaka, K.; Ushiku, T.; Kaneda, A. Thirty years of Epstein-Barr virus-associated gastric carcinoma. Virchows Archiv 2020, 476, 353-365.

9. Aboulkassim T, Yasmeen A, Akil N, Batist G, Al Moustafa AE. Incidence of EpsteinBarr virus in Syrian women with breast cancer: a tissue microarray study. Hum Vaccine Immunother. (2015) 11: 951-5.

10. Lawson JS, Glenn WK, Salyakina D, Delprado W, Clay R, Antonsson A, et al. Human papilloma viruses and breast cancer. Front Oncol. (2015) 5: 277.

11. Al Moustafa AE, Al-Antary N, Aboulkassim T, Akil N, Batist G, Yasmeen A. Co-prevalence of Epstein-Barr virus and high-risk human papillomaviruses in Syrian women with breast cancer. Hum Vaccine Immunother. (2016) 12: 1936-9.

12. Lawson JS, Glenn WK. Multiple oncogenic viruses are present in human breast tissues before development of virus associated breast cancer. Infect Agents Cancer. (2017) 12:55.

13. Al Hamad M, Matalka I, Al Zoubi MS, Armogida I, Khasawneh R, Al-Husaini M, et al. Human mammary tumor virus, human papilloma virus, and Epstein- Barr virus infection are associated with sporadic breast cancer metastasis. Breast Cancer. (2020) 14: 1178223420976388.

14. Yahia ZA, Adam AA, Elgizouli M, Hussein A, Masri MA, Kamal M, et al. Epstein Barr virus: a prime candidate of breast cancer aetiology in Sudanese patients. Infect Agents Cancer. (2014) 9: 9-9. 
15. Gupta I, Nasrallah GK, Sharma A, Jabeen A, Smatti MK, Al-Thawadi HA, et al. Coprevalence of human Papillomaviruses (HPV) and Epstein-Barr virus (EBV) in healthy blood donors from diverse nationalities in Qatar. Cancer Cell Int. (2020) 20: 107.

16. Deshpande CG, Badve S, Kidwai N, Longnecker R. Lack of expression of the Epstein-Barr virus (EBV) gene products, EBERs, EBNA1, LMP1, and LMP2A, in breast cancer cells. Lab Invest. (2002) 82: 1193-9.

17. Preciado, MV Lack of evidence for an association of Epstein-Barr virus infection with breast carcinoma - another point of view. Breast Cancer Res. 2003, 5, E6.

18. Kadivar M, Monabati A, Joulaee A, Hosseini N. Epstein-Barr virus and breast cancer: lack of evidence for an association in Iranian women. Pathol Oncol Res. (2011) 17: 489-92.

19. Huo, Q.; Zhang, N.; Yang, Q. Epstein-Barr Virus Infection and Sporadic Breast Cancer Risk: A Meta-Analysis. PLoS ONE 2012, 7.

20. Sung H, Ferlay J, Siegel RL, Laversanne M, Soerjomataram I, Jemal A, et al. Global cancer statistics 2020: GLOBOCAN estimates of incidence and mortality worldwide for 36 cancers in 185 countries. CA Cancer J Clin [Internet]. [Cited March 8, 2021]; $\mathrm{n} / \mathrm{a}$ (n / a). Available at: https: // acs

journals.onlinelibrary.wiley.com/doi/abs/10. 3322 / caac. 21660.

21. Moudiongui Mboungou M., D., Boumba A., L., Malonga G., A., et.al. Breast cancer in women: epidemiological, histological, immunohistochemical and molecular subtypes in the Republic of Congo. Int J Health Sci Res. 2021; 11 (5): 103-116.

22. Niesters HG, van Esser J., Fries E., Wolthers K. C., Cornelissen J. and Osterhaus AD Development of a real-time quantitative assay for detection of EpsteinBarr virus. J Clin Microbiol 2000; 38: 7125.

23. Benson, JR, \& Jatoi, I. The global breast cancer burden. Future oncology, 2012; 8 (6): 697-702.

24. Golrokh Mofrad M, Sadigh ZA, Ainechi S, Faghihloo E. Detection of human papillomavirus genotypes, herpes simplex, varicella zoster and cytomegalovirus in breast cancer patients. Virol J. 2021; 18 (1): 25.

25. Forouzanfar MH, Foreman KJ, Delossantos AM, et al. Breast and cervical cancer in 187 countries between 1980 and 2010: a systematic analysis. Lancet 2011; 378 : 1461-84.

26. Yu F, Lu Y, Li Y, Uchio Y, Pangnguriseng UA, Kartika AV, et al. Epstein - Barr Virus Infection of Pseudostratified Nasopharyngeal Epithelium Disrupts Epithelial Integrity. Cancers. 2020; 12 (9): 2722.

27. Naushad W, Surriya O, Sadia H. Prevalence of EBV, HPV and MMTV in Pakistani breast cancer patients: a possible etiological role of viruses in breast cancer. Infect Genet Evol 2017; 54: 230-237.

28. Rogier B, Peter RWAVR, Anita CS, et al. Virus characterization and discovery in formalin-fixed paraffin- embedded tissues. J Virol Methods 2015; 214: 54-59.

29. Sharifpour C, Makvandi M, Samarbafzadeh A, et al. Frequency of Epstein-Barr virus DNA in formalin-fixed paraffin-embedded tissue from patients with ductal carcinoma of the breast. Asian Pac J Cancer Prev. 2019; 20 (3): 687-692.

30. Bodewes R, Sánchez CGJ, Rubio GA, et al. Identification of DNA sequences that imply a novel gamma herpesvirus in seals. J Gen Virol 2014;10: 0.000029.

31. Cimino, PJ, Zhao GWD, Sehn JK, et al. Detection of viral pathogens in high grade gliomas from unmapped next-generation sequencing data. Exp Mol Pathol 2014; 96: 310-15.

32. Tumpey TM, Basler CF, Aguilar PV, et al. Characterization of the reconstructed 1918 Spanish influenza pandemic virus. Science 2005; 310: 77-80.

33. Balfour, $\mathrm{HH}$ et al. Age-specific prevalence of Epstein - Barr virus infection among individuals aged 6-19 years in the United States and factors affecting its acquisition. J. Infect. Say. 2013; 208: 1286-1293.

34. Green, M. \& Michaels, MG Epstein - Barr virus infection and posttransplant lymphoproliferative disorder: EBV and PTLD. Am. J. Transplant. 2013; 13: 41-54.

35. Pender, MP The essential role of Epstein Barr virus in the pathogenesis of multiple sclerosis. Neuroscientist 2011; 17: 351-367.

36. Pender, MP \& Burrows, SR Epstein - Barr virus and multiple sclerosis: potential 
opportunities for immunotherapy. Clin. Transl. Immunol. 2014; 3: e27.

37. Farina, A. et al. Epstein - Barr virus lytic infection promotes activation of Toll-like receptor 8 innate immune response in systemic sclerosis monocytes. Arthritis Res. Ther. 2017; 19:39.

38. Ruprecht, K. The role of Epstein - Barr virus in the etiology of multiple sclerosis: a current review. Expert Rev. Clin. Immunol. 2020; 0: 1-15.

39. Young, LS \& Rickinson, AB Epstein - Barr virus: 40 years on. Nat. Rev. Cancer 2004; 4: 757-768.

40. Ko, Y.-H. EBV and human cancer. Exp. Mol. Med. 47, e130 (2015).

41. de Martel, C. et al. Global burden of cancers attributable to infections in 2008: a review and synthetic analysis. Lancet Oncol 2012; 13: 607-615.

42. Khan, G. \& Hashim, MJ Global burden of deaths from Epstein - Barr virus attributable malignancies 1990-2010. Infect. Agents Cancer 2014; 9:38.

43. Naseem, M.; Barzi, A.; Brezden-Masley, C.; Puccini, A.; Berger, MD; Tokunaga, R.; Battaglin, F.; Soni, S.; McSkane, M.; Zhang, W.; et al. Outlooks on Epstein-Barr virus associated gastric cancer. Cancer Treat. Rev. 2018, 66, 15-22.

44. Fukayama, M.; Abe, H.; Kunita, A.; Shinozaki-Ushiku, A.; Matsusaka, K.; Ushiku, T.; Kaneda, A. Thirty years of Epstein-Barr virus-associated gastric carcinoma. Virchows Archiv 2020; 476: 353-365.

45. Labrecque, LG; Barnes, DM; Fentiman, IS; E Griffin, B. Epstein-Barr virus in epithelial cell tumors: A breast cancer study. Cancer Res. 1995, 55, 39-45.

46. Glaser, SL; Ambinder, RF; DiGiuseppe, JA; Horn-Ross, PL; Hsu, JL Absence of Epstein-Barr virus EBER-1 transcripts in an epidemiologically diverse group of breast cancers. Int. J. Cancer 1998, 75, 555-55.

47. Fina, F.; Romain, S.; Ouafik, L.; Palmari, J.; Ben Ayed, F.; Benharkat, S.; Bonnier, P.; Spyratos, F.; A Foekens, J.; Rose, C.; et al. Frequency and genome load of Epstein-Barr virus in 509 breast cancers from different geographical areas. Br. J. Cancer 2001, 84, 783-790.

48. Bonnet M, Guinerbretiere JM, Kremmer E, et al. Detection of Epstein-Barr virus in invasive breast cancers. J Natl Cancer Inst 1999; 61: 1376-81.

49. Gaffey MJ, Frierson HF, Mills SE, et al. Medullary carcinoma of the breast. Identification of lymphocyte subpopulations their significance. Mod Pathol 1993; 6: 7218.

50. Lespagnard L, Cochaux P, Larsimont D. Absence of Epstein-Barr virus in medullary carcinoma as demonstrated by immunophenotyping, in situ hibridization and polymerase chain reaction. Am J Clin Pathol 1995; 103: 449-52.

51. Fina F, Romain S, Ouafik L, et al. Frequency and genome load of Epstein-Barr virus in 509 breast cancer from different geographical areas. Br J Cancer 2001; 84: 783-90.

52. Huo, Q., Zhang, N., \& Yang, Q. EpsteinBarr virus infection and sporadic breast cancer risk: a meta-analysis. PloS one, 2012; 7 (2): e31656.

53. Farahmand M, Monavari SH, Shoja Z, Gha ff ari H, Tavakoli M, Tavakoli A, EpsteinBarr virus and risk of breast cancer: a systematic review and meta-analysis, Future Oncol, 15 (24): 2873-2885, 2019.

54. Yahia, ZA, Adam, AA, Elgizouli, M., Hussein, A., Masri, MA, Kamal, M., ... \& Ibrahim, ME. Epstein Barr virus: a prime candidate for the etiology of breast cancer in Sudanese patients. Infectious agents and cancer 2014; 9 (1): 1-5.

55. Naushad, W., Surriya, O., \& Sadia, H. Prevalence of EBV, HPV and MMTV in Pakistani breast cancer patients: a possible etiological role of viruses in breast cancer. Infection, Genetics and Evolution, 2017; 54: 230-237.

56. Mofrad, MG, Kazeminezhad, B., \& Faghihloo, E. Prevalence of Epstein - Barr virus (EBV) in Iranian breast carcinoma patients. Asian Pacific journal of cancer prevention: APJCP, 2020; 21 (1): 133.

57. Mazouni, C., Fina, F., Romain, S., Ouafik, L., Bonnier, P., Brandone, JM, \& Martin, PM Epstein-Barr virus as a marker of biological aggressiveness in breast cancer. British journal of cancer, 2011; 104 (2): 332-337.

58. Jha, HC, Pei, Y., \& Robertson, ES. EpsteinBarr virus: infection and transformationrelated diseases. Frontiers in microbiology 2016; 7: 1602. 
59. Sun, J., Hu, C., Zhu, Y., Sun, R., Fang, Y., Fan, Y., \& Xu, F. LMP1 increases expression of NADPH oxidase (NOX) and its regulatory subunit p22 in NP69 nasopharyngeal cells and makes them sensitive to a treatment by a NOX inhibitor. PloS one, 2015; 10 (8): e0134896.

60. Kafe H, Wechsler J, Gaulard P, Gosselin B. The Epstein-Barr virus: implication in pathology. Ann Pathol 1998; 18: 16-28.

61. Frappier, Lori. "Role of EBNA1 in NPC tumourigenesis." Seminars in cancer biology, 2012; 22 (2): 154-161.

62. Herrmann K, Niedobitek G. Lack of evidence for an association of Epstein-Barr virus infection with breast carcinoma. Breast Cancer Res 2003; 5: R13-R17.

63. Kadivar, M., Monabati, A., Joulaee, A., \& Hosseini, N. Epstein-Barr virus and breast cancer: no evidence of an association in Iranian women. Research in pathology and oncology 2011; 17 (3): 489-492.
64. Horiuchi K, Mishima K, Ohsawa M, Aozasa $\mathrm{K}$. Carcinoma of sto- mach and breast with lymphoid stroma: localization of EpsteinBarr virus. J Clin Pathol 1994; 47: 538-40.

65. Sharifpour, C., Makvandi, M., Samarbafzadeh, A., Talaei-Zadeh, A., Ranjbari, N., Nisi, N., ... \& Angali, KA (2019). Frequency of Epstein - Barr virus DNA in formalin-fixed paraffin-embedded tissue of patients with ductal breast carcinoma. Asian Pacific journal of cancer prevention: APJCP, 20 (3), 687.

66. Labrecque LG, Barnes DM, Fentiman IS, et al. Epstein-Barr virus in epithelial cell tumors: a breast cancer study. Cancer Res 1995; 55: 39-45.

How to cite this article: Malanda DMM, Boumba ALM, Mouamba FG et.al. Molecular epidemiology of Epstein-Barr virus in women breast cancer in Congo Brazzaville. Int $J$ Health Sci Res. 2021; 11(11): 180-190. DOI: https:// doi.org/10.52403/ijhsr.20211124 